\title{
Synthesis, structure analysis, anti-bacterial and in vitro anti-cancer activity of new Schiff base and its copper complex derived from sulfamethoxazole
}

\author{
I RAMA* and R SELVAMEENA \\ PG and Research Department of Chemistry, Seethalakshmi Ramaswami College, \\ Tiruchirappalli 620 002, Tamil Nadu, India \\ e-mail: rama14jai@yahoo.co.in
}

MS received 1 May 2014; revised 14 October 2014; accepted 18 October 2014

\begin{abstract}
A new bidentate Schiff base ligand $\left(\mathrm{HL}^{1}\right)$, containing $\mathrm{O}, \mathrm{N}$ donors was prepared by the reaction of sulfamethoxazole with 5-nitrosalicylaldehyde and characterized by elemental analysis, FT-IR, ${ }^{1} \mathrm{H}$ and ${ }^{13} \mathrm{C}$ NMR. The copper complex of this ligand was synthesised by treating DMF-ethanolic mixture solution of the ligand of two equivalents with one equivalent of copper acetate. The complex was characterized on the basis of UV, FT-IR, molar conductance, EPR, magnetic moment and single crystal X-ray diffraction. Interestingly, the crystal structure of the octahedral complex showed two solvent molecules (DMF) as ligands at their axial positions. The molar conductance data revealed that the complex is a non-electrolyte. The Schiff base and its copper complex have been investigated as anti-bacterial and anti-fungal agents against various microorganisms. The in vitro cytotoxicity tests of the ligand and its copper complex were carried out in two different human tumour cell lines, HCT-116 and MDA - MB - 231. The cytotoxicity studies showed that the complex exhibited higher activity than cisplatin and carboplatin towards MDA - MB -231 .
\end{abstract}

Keywords. Synthesis; metal complexes; x-ray diffraction studies; sulfadrug; non-electrolyte; cytotoxicity studies.

\section{Introduction}

A large number of Schiff base ligands derived from the combination of amine and an aldehyde or ketone are useful chelates for obtaining coordination spheres with mixed N/O donors. Interest in these ligands has been driven, in part, due to potential beneficial biological activity of the ligands and their metal complexes, including anti-malarial, ${ }^{1}$ anti-bacterial, ${ }^{2}$ anti-fungal, ${ }^{3}$ anti-viral activity, ${ }^{4}$ and an excellent lead for the development of anti-tubercular agent. ${ }^{5}$ Biological activities of metal complexes differ from those of either ligands or the metal ions and increased and/or decreased biological activities have been reported for several metal complexes, like Pd(II). ${ }^{6}$ Schiff bases have been widely explored for industrial applications also. These have been studied extensively due to their flexibility, selectivity and sensitivity towards the central metal atom and structural similarities with natural biological substances and the presence of imine group $(-\mathrm{N}=\mathrm{CH}-)$ imparts biological activity. ${ }^{7}$ The topical application of metal complexes of sulfadiazine has recently revived the usefulness of these compounds in medicine. ${ }^{8}$ Indeed metal

\footnotetext{
*For correspondence
}

sulfadiazine complexes are now widely used to prevent bacterial infection during burn treatment. ${ }^{9}$ It should be emphasized that despite the interesting biological activity of Schiff bases derived from sulfa drugs, no single crystal X-ray diffraction analysis has been reported for its transition metal complexes, as yet. As a part of our investigation, the present work reports the synthesis, characterization and biological activities of the ligand $\left(\mathrm{HL}^{1}\right)$ and its copper complex. The structure of the complex was determined by single crystal X-ray study.

\section{Experimental}

\subsection{Materials and measurements}

All chemicals and reagents used were of analytical reagent grade (AR) except ethanol which was purified prior to use. ${ }^{10}$ Conductance measurements were studied using Elico conductivity bridge and dip type conductivity cell. Elemental analyses were carried out with an Elemental Vario EL III model. IR spectra were recorded as $\mathrm{KBr}$ pellets on a SHIMADZU 8000 FTIR spectrophotometer in the range of $4000-400 \mathrm{~cm}^{-1}$. Absorbance spectra were recorded on a SHIMADZU spectrophotometer in the range of $300-1000 \mathrm{~nm} .{ }^{1} \mathrm{H}$ and 
${ }^{13}$ CNMR spectra of ligand was recorded with a Bruker Spectrospin Avance DPX-400 using TMS as internal standard and DMSO- $d_{6}$ as solvent. Magnetic susceptibility measurement was carried out on solid complex using Gouy balance at room temperature. Melting points of the ligand and its copper complex were determined by open capillary method using Silicon bath electric melting point apparatus and uncorrected. The X-band EPR studies were carried out in JEOL Model JES FA 200 at liquid nitrogen temperature. In vitro anti-bacterial and anti-fungal studies were carried out at Periyar college of Pharmaceutical sciences, Tiruchirappalli.

\section{$2.2 X$-ray crystallography}

2.2a Data collection: Bruker AXS with CCD area detector, temperature 293(2) $\mathrm{K}$, MoK $\alpha$ radiation $(\lambda=$ $0.71073 \AA$ ) graphite monochromator, $\omega$ scans, data collection and cell refinement with SMART, ${ }^{11}$ data reduction with SAINT, ${ }^{11}$ experimental absorption correction with SADABS. ${ }^{12}$

$2.2 \mathrm{~b}$ Structure analysis and refinement: The structure was solved by direct method (SHELXS-97) refinement was done by full - matrix least-squares on $\mathrm{F}^{2}$ using the SHELXS-97 program suite. ${ }^{13}$ All hydrogen atoms were found in difference electron maps and were subsequently refined in a riding model approximation with $\mathrm{C}-\mathrm{H}$ distance ranging from 0.93 to $0.96 \AA$. The materials for publication were prepared using Mercury and ORTEP-3 programs. ${ }^{14}$ Crystallographic data and details of the data collection and structure refinements are listed in table 1.

\subsection{Synthesis}

2.3a Preparation of ligand $\left(H L^{1} / N S S M O\right)$ : To a stirred ethanolic solution of sulfamethoxazole $(0.1 \mathrm{mmol})$, ethanolic solution of 5-nitrosalicylaldehyde $(0.1 \mathrm{mmol})$ was added and the mixture was refluxed for $3 \mathrm{~h}$. The precipitate obtained was filtered off, washed with ethanol, dried in vacuum over anhydrous calcium chloride and recrystallised.Yield: $84 \%$, M.p. $218^{\circ} \mathrm{C}$, Anal. Found (Calcd.)(\%) for $\mathrm{C}_{17} \mathrm{H}_{14} \mathrm{~N}_{4} \mathrm{O}_{6} \mathrm{~S}(402 \mathrm{~g} / \mathrm{mol})$ : C 49.98 (50.74), H 3.09 (3.51), N 13.59 (13.92), S 8.10 (7.97). IR (Solid state, $\left.\mathrm{cm}^{-1}\right): v(-\mathrm{C}=\mathrm{N}-)$ 1608; $v(\mathrm{O}-\mathrm{H}) 3504$; $v(\mathrm{C}-\mathrm{O}) 1475 ; v_{\mathrm{a}}\left(\mathrm{SO}_{2}\right) 1398 ; v_{\mathrm{s}}\left(\mathrm{SO}_{2}\right) 1168 ; v(\mathrm{~S}-\mathrm{N})$ 937; v (C-S) 835; ${ }^{1} \mathrm{HNMR}\left(\mathrm{DMSO}-d_{6}\right): \delta 8.928(\mathrm{~s}, \mathrm{H})$; $\delta 11.48(\mathrm{~s}, \mathrm{H}) ; \delta 12.32(\mathrm{~s}, \mathrm{H})$, Electronic spectra $\left(\lambda_{\max }\right.$ $\mathrm{cm}^{-1}$ ) 32,594 (n $\left.\rightarrow \pi *\right) ; 23,657$ (INCT).

2.3b Preparation of copper complex $\left(\left[\mathrm{Cu}\left(\mathrm{L}^{1}\right)_{2}\right.\right.$ $\left.\left.(D M F)_{2}\right] / N S S M O C u\right)$ : To a warm solution of copper acetate $(0.1 \mathrm{mmol})$ in ethanol, DMF-ethanol solution of ligand $(0.2 \mathrm{mmol})$ was added. The mixture was refluxed for $6 \mathrm{~h}$, and the precipitate obtained on partial evaporation was collected by suction filtration and washed

Table 1. Crystal data and structure refinement for $\left[\mathrm{Cu}\left(\mathrm{L}^{1}\right)_{2}(\mathrm{DMF})_{2}\right]$.

\begin{tabular}{ll}
\hline Identification code & NSSMOCu \\
CCDC number & 985349 \\
Empirical formula & $\mathrm{C}_{40} \mathrm{H}_{40} \mathrm{Cu} \mathrm{N}_{10} \mathrm{O}_{14} \mathrm{~S}_{2}$ \\
Formula weight & 1012.48 \\
Temperature & $293(2) \mathrm{K}$ \\
Wavelength & $0.71073 \AA$ \\
Crystal system, & Triclinic, \\
Space group & $\mathrm{P}-1$ \\
$a, \mathrm{~b}, \mathrm{c}(\AA)$ & $8.4103(4), 10.6582(6), 13.2405(7)$ \\
$\alpha, \beta, \gamma\left({ }^{\circ}\right)$ & $80.543(2), 76.990(2), 79.451(2)$ \\
Volume & $1127.42(10) \mathrm{A}^{3}$ \\
$Z$, Calculated density & $1,1.491 \mathrm{~g} / \mathrm{cm}^{3}$ \\
Absorption coefficient & $0.655 \mathrm{~mm}^{-1}$ \\
F(000) & 523 \\
$\theta$ range for data collection & $1.96-25.20^{\circ}$ \\
Limiting indices & $-10: 10 ;-12: 12 ;-15: 15$ \\
Reflections collected / unique & $36294 / 4059[\mathrm{R}(\mathrm{int})=0.0271]$ \\
Completeness to $\theta$ & $25.2099 .7 \%$ \\
Absorption correction & Semi-empirical from equivalents \\
Refinement method & Full-matrix least-squares on $\mathrm{F}^{2}$ \\
Data / restraints / parameters & $4059 / 74 / 337$ \\
$\mathrm{~S}$ & 1.149 \\
Final R indices [I $>2 \sigma(\mathrm{I})]$ & $\mathrm{R} 1=0.0364$, wR2 $=0.0876$ \\
Largest diff. peak and hole & 0.404 and -0.368 e. $\mathrm{A}^{-3}$ \\
\hline
\end{tabular}


with ethanol several times and recrystallised. Yield: $60 \%$, M.p. $290^{\circ}$ C, Anal. Found (Calcd.)(\%) for $\mathrm{C}_{40} \mathrm{H}_{40}$ $\mathrm{N}_{10} \mathrm{O}_{14} \mathrm{~S}_{2}$ (1012 g/mol): C 46.72 (47.45), H 3.89 (3.98), N 13.43 (13.83), S 6.38 (6.33), M 6.49 (6.28). IR (Solid state, cm-1): v(-C=N-) 1649; v (C-O) 1479; $v_{\mathrm{a}}$ $\left(\mathrm{SO}_{2}\right) 1342 ; v_{\mathrm{s}}\left(\mathrm{SO}_{2}\right) 1163 ; v(\mathrm{~S}-\mathrm{N}) 931 ; v(\mathrm{C}-\mathrm{S}) 842$; $v(\mathrm{M}-\mathrm{O}) 526 ; v(\mathrm{M}-\mathrm{N})$ 410. Electronic spectra $\left(\lambda_{\max }\right.$ $\left.\mathrm{cm}^{-1}\right)$ 26,525 (n $\left.\rightarrow \pi *\right) ; 22,500\left({ }^{2} \mathrm{E}_{1 \mathrm{~g}} \rightarrow{ }^{2} \mathrm{~T}_{2 \mathrm{~g}}\right)$.

\section{Results and Discussion}

\subsection{Characterization of the ligand}

The Schiff base ligand $\mathrm{HL}^{1}$ was prepared by the interaction of 5-nitro salicylaldehyde and sulfamethoxazole in ethanol according to scheme 1. The ligand was soluble only in DMF, DMSO, dioxane and partially soluble in toluene and insoluble in ethanol, methanol and acetonitrile. The composition of the ligand was consistent with the micro analytical data.

The ${ }^{1} \mathrm{H}$ NMR spectral data (figure $\mathrm{S} 1$ ) reveals the appearance $^{15}$ of the azomethine proton $(-\mathrm{CH}=\mathrm{N})$ signal at $8.90 \mathrm{ppm}$. This is further supported ${ }^{16}$ by the appearance of a band for $v(-\mathrm{HC}=\mathrm{N})$ (azomethine) at $1618 \mathrm{~cm}^{-1}$ in the IR spectrum of the ligand. The IR spectrum of the ligand also exhibits relevant bands for phenolic $v(\mathrm{O}-\mathrm{H}), v(\mathrm{C}-\mathrm{O}), v(\mathrm{~N}-\mathrm{H}), v_{\text {as }}\left(\mathrm{SO}_{2}\right)$ and $v_{\mathrm{sy}}\left(\mathrm{SO}_{2}\right)$, which also support the formation of Schiff base ligand.

\subsection{Characterization of metal complex}

The synthesis of the mononuclear copper(II) complex (scheme 2) was achieved by refluxing the bidentate
Schiff-base ligand ( $\left.\mathrm{HL}^{1}\right)$ and copper(II) acetate in a 2:1 molar ratio for $6 \mathrm{~h}$ in $\mathrm{DMF}-$-ethanol solution.

The resulting complex is soluble in DMF and DMSO, partially soluble in toluene and insoluble in ethanol, methanol and acetonitrile. Elemental analysis confirmed a stoichiometric formula of the complex as $\left[\mathrm{Cu}\left(\mathrm{L}^{1}\right)_{2}(\mathrm{DMF})_{2}\right]$. The molar conductance value (in DMF) for the complex is $13.83 \Omega^{-1} \mathrm{~cm}^{2} \mathrm{~mol}^{-1}$, showing its non-electrolytic ${ }^{17}$ nature. The room temperature magnetic moment value of the complex is 1.79 B.M. lie in the range expected for a $\mathrm{d}^{9}$-system, which contains one unpaired electron with octahedral geometry. ${ }^{18}$ The complex was characterized by the following studies.

3.2a IR, UV, NMR and EPR spectra of the complexes: The ligand shows a strong IR band at 1608 $\mathrm{cm}^{-1}$ attributed to $v(\mathrm{C}=\mathrm{N})$ stretching vibration. This band is shifted to a higher frequency $\left(1649 \mathrm{~cm}^{-1}\right)$ in the complex compared with those of the Schiff-base ligand showing the coordination of the imino-nitrogen ${ }^{19}$ to the copper atom. This is further confirmed by the appearance of a new band at $410 \mathrm{~cm}^{-1}$ due to the $v(\mathrm{M}-\mathrm{N})^{20}$ band. The coordination through the phenolic oxygen after deprotonation is revealed by the disappearance of the $v(\mathrm{OH})$ phenolic band at $3504 \mathrm{~cm}^{-1}$ and the shift of phenolic $v(\mathrm{C}-\mathrm{O})^{21}$ band to higher frequency 1479 $\mathrm{cm}^{-1}$ in the complex as compared to that of the ligand at $1475 \mathrm{~cm}^{-1}$. This is further confirmed by the appearance of a new non-ligand band at $526 \mathrm{~cm}^{-1}$ due to $v(\mathrm{M}-\mathrm{O})^{22}$ in the complex. The overall data suggest that the azomethine- $\mathrm{N}$ and phenolic-O groups are involved in coordination with the metal (II) ion in the complex. The metal complex shows two new bands at around $1614 \mathrm{~cm}^{-1}$ and $605 \mathrm{~cm}^{-1}$ attributed to the carbonyl stretching vibration and $v(\mathrm{M}-\mathrm{O})^{23}$ band respectively.

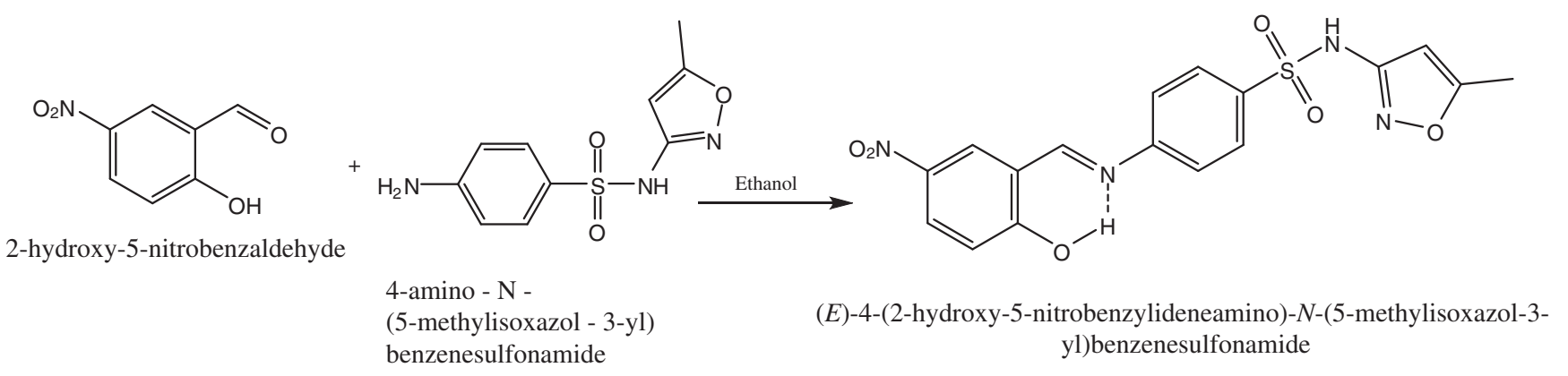

Scheme 1. Preparation of ligand.

\section{DMF/Ethanol $\mathrm{Cu}\left(\mathrm{CH}_{3} \mathrm{COO}\right)_{2}+2 \mathrm{HL}^{1} \longrightarrow\left[\mathrm{Cu}\left(\mathrm{L}^{1}\right)_{2}(\mathrm{DMF})_{2}\right]+2 \mathrm{CH}_{3} \mathrm{COOH}$}

Scheme 2. Synthesis of copper complex. 
This is not shown in the ligand, which is due to the coordination of the carbonyl group of the solvent DMF to the metal ion and this is also revealed through the crystal studies.

The electronic spectral data of the ligand and its copper complex were recorded by using DMF solution of concentration $10^{-3} \mathrm{~mol} / \mathrm{dm}^{3}$. The absorption spectrum of $\mathrm{HL}^{1}$ is characterized mainly by two absorption bands at $32,594 \mathrm{~cm}^{-1}$ and $23,657 \mathrm{~cm}^{-1}$. The first peak is attributed to transition between $\pi$-orbital localized on the central azomethine bond ${ }^{24}$ and longer wavelength band at $23,657 \mathrm{~cm}^{-1}$ assigned to intra molecular charge transfer of phenolic $\mathrm{OH}^{25}$ respectively. The band at $26,525 \mathrm{~cm}^{-1}$ can be assigned to $\mathrm{n} \rightarrow \pi^{*}$ (imine) transition. ${ }^{26}$ The peak that appears at $22,500 \mathrm{~cm}^{-1}$ is assigned to the transition ${ }^{2} \mathrm{E}_{1 \mathrm{~g}} \rightarrow{ }^{2} \mathrm{~T}_{2 \mathrm{~g}}$ confirms octahedral geometry (figure 1$) .{ }^{27}$ The packing view of the octahedral complex is in figure 2 .

The ${ }^{1} \mathrm{H}$ NMR spectrum of the ligand is given in the figure S1, along with indexing of various types of protons. The formation of Schiff base ligand is revealed by the appearance of the azomethine proton $(-\mathrm{CH}=\mathrm{N}-$ ) signal at $8.90 \mathrm{ppm} .{ }^{28}$ The ligand exhibits signal for aromatic protons, $-\mathrm{NH}$ group and phenolic $-\mathrm{OH}$ group at 6.16 to $7.92,12.32$ and $11.48 \mathrm{ppm}$, respectively. ${ }^{29}$

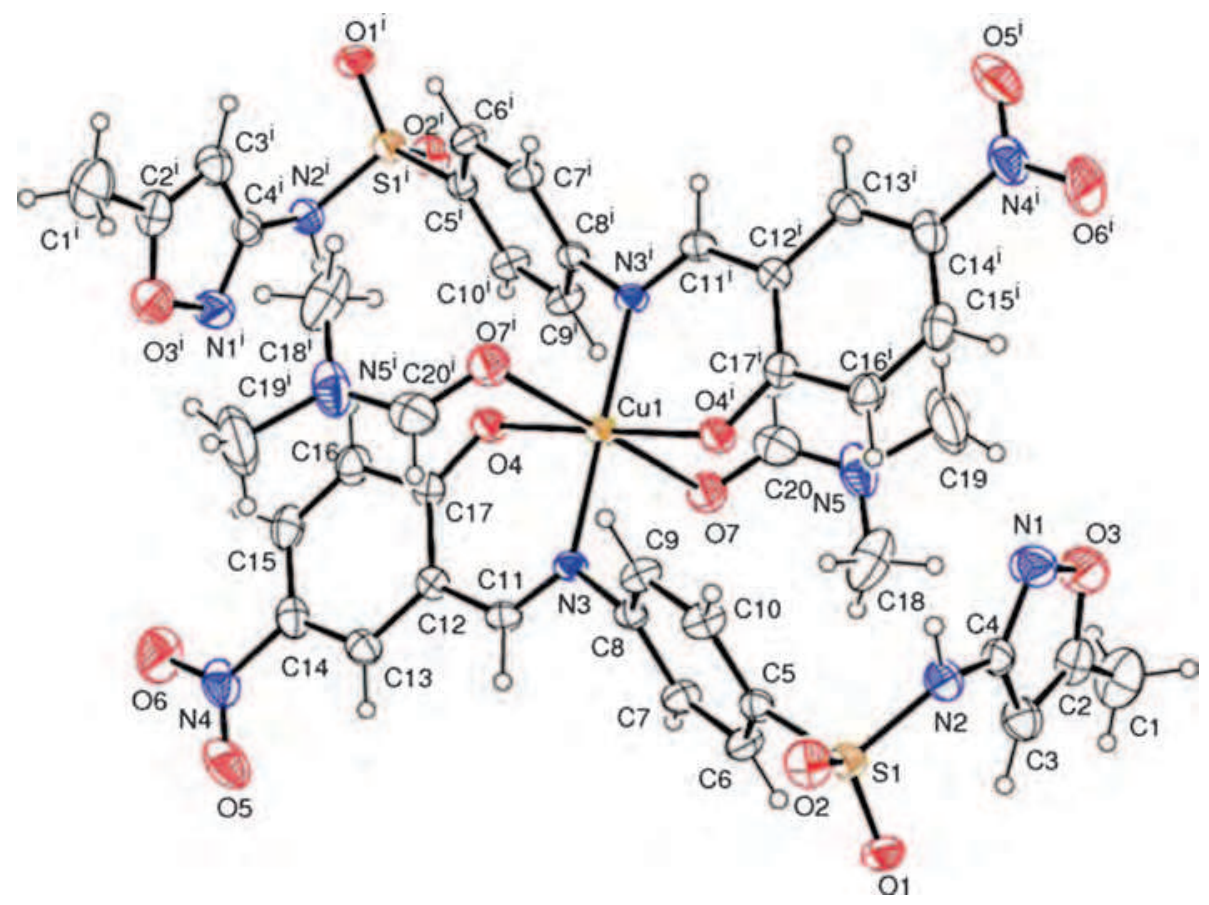

Figure 1. ORTEP view of $\left[\mathrm{Cu}\left(\mathrm{L}^{1}\right)_{2}(\mathrm{DMF})_{2}\right]$.

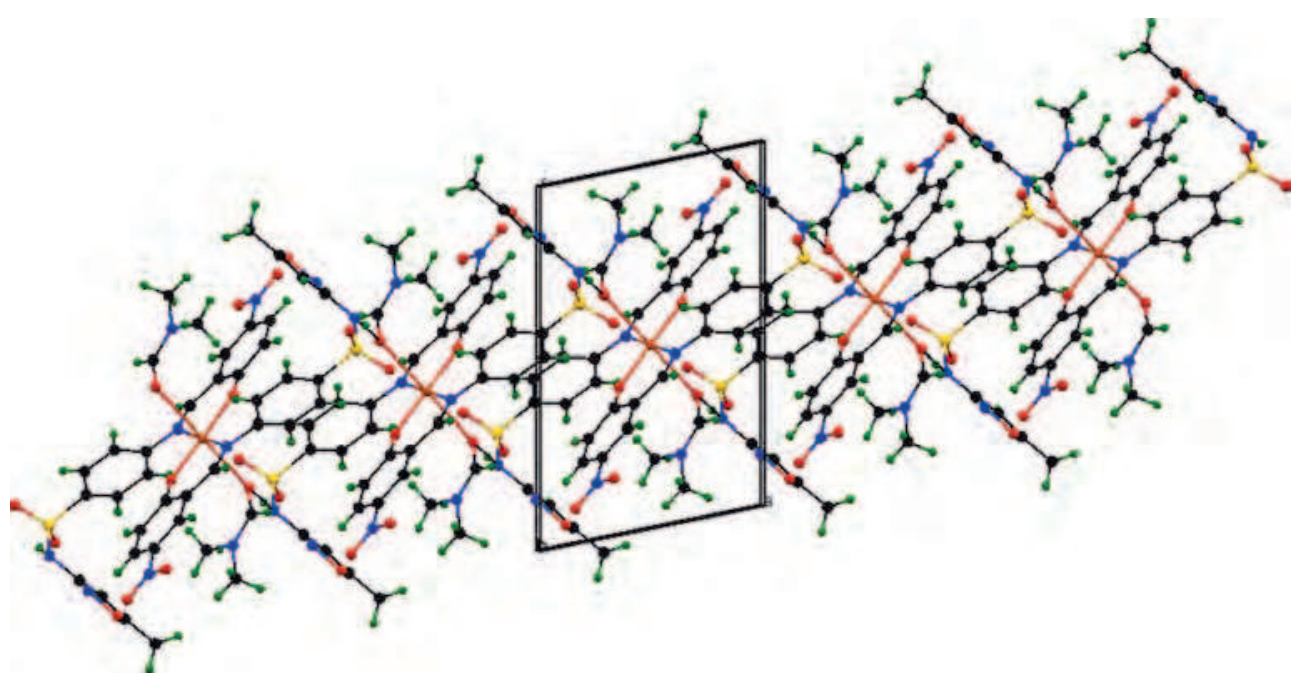

Figure 2. Packing view of $\left[\mathrm{Cu}\left(\mathrm{L}^{1}\right)_{2}(\mathrm{DMF})_{2}\right]$. 
In addition, the number of protons calculated from the integration curves and those obtained from the values of the expected $\mathrm{CHN}$ analysis, agree well with each other. The appearance of singlet at $159.18 \mathrm{ppm}$ in the ${ }^{13} \mathrm{C}$ spectrum confirms the presence of azomethine $(-\mathrm{CH}=\mathrm{N}-)$ carbon $^{30}$ and the carbon atoms of aromatic groups were found to be in their expected region. The conclusions drawn from these studies further support the mode of bonding discussed in their IR and ${ }^{1} \mathrm{H}$ NMR spectra.

The EPR spectrum of copper complex provides information about the metal ion environment. The X-band EPR spectra of the copper complex at liquid nitrogen temperature is presented in figure 3 . The spectrum of the copper complex in the frozen state shows four well resolved peaks in the low field region. The copper complex exhibits the $g_{\|}$value of 2.223 and $g_{\perp}$ value of 2.023. These values indicate that the ground state of copper(II) is predominantly $\mathrm{dx}_{2}-\mathrm{y}_{2}$ and the $\mathrm{Cu}^{2+}$ ion being located in distorted octahedral sites elongated along the z-axis. ${ }^{31,32}$ The spin-orbit coupling constant, $\lambda$ value $\left(-472.5 \mathrm{~cm}^{-1}\right)$ calculated using the relation $\mathrm{g}_{\mathrm{av}}=2(1-2 \lambda / 10 \mathrm{Dq})$, is less than the free $\mathrm{Cu}(\mathrm{II})$ ion $\left(-832 \mathrm{~cm}^{-1}\right)$ which also supports covalent character $^{33}$ of M-L bond in the complex. The EPR spectrum has asymmetric bands with two ' $\mathrm{g}$ ' values, and $\mathrm{g}_{\|>} \mathrm{g}_{\perp}$. This trend indicates that the copper exhibits a distorted octahedral geometry. ${ }^{33}$ The reason for the distortion of the coordination sphere from octahedral geometry is to attain the stability through the Jahn-Teller effect. 3.2b Description of the crystal structure of $\left[\mathrm{Cu}\left(L^{1}\right)_{2}\right.$ $\left.(D M F)_{2}\right]$ : The single crystal of $\left[\mathrm{Cu}\left(\mathrm{L}^{1}\right)_{2}(\mathrm{DMF})_{2}\right]$ suitable for X-ray diffraction study was obtained by a diffusion method similar to the condition for the synthesis of the copper (II) complex. A perspective view of the complex is shown in figure 1 and selected bond lengths and angles are summarized in table 2 . The complex crystallizes in the triclinic space group P-1, with one asymmetric unit constituted by a molecule of complex alone without any counter anion such as acetate ion. In the structure of copper complex, the $\mathrm{Cu}^{2+}$ ion lies in a distorted octahedral geometry, in which the two molecules of the symmetrical ligand $\mathrm{HL}^{1}$ are coordinated through two deprotonated phenolateoxygen and two imino nitrogen atoms to form the equatorial plane, with atoms of the same type in trans positions with respect to each other, while two carbonyl groups of DMF are at axial planes to complete the coordination sphere of the $\mathrm{Cu}^{2+}$ cation. As can be observed in figure 1, the donor atoms N3, O4 and O7 occupy one face of the octahedron while N3a, O4a and O7a occupy the other face. The two axial $\mathrm{Cu}-\mathrm{O} 7 / \mathrm{Cu}-\mathrm{O} 7 \mathrm{a}$ bond distances of 2.669(2) $\AA$ in the complex are considerably longer than the equatorial bond distances between the $\mathrm{Cu}^{\mathrm{II}}$ ion and the $\mathrm{O} / \mathrm{N}$ atom of the ligand as a consequence of the Jahn-Teller effect. ${ }^{34}$ The angles between the $\mathrm{Cu}^{\mathrm{II}}$ ion and the coordinating $\mathrm{N}$ and $\mathrm{O}$ atoms vary between $84.24(8)^{\circ}[\mathrm{N} 3-\mathrm{Cu} 1-\mathrm{O} 4]$ and $95.76(8)^{\circ}$ [N3- $\mathrm{Cu} 1-\mathrm{O} 7]$.

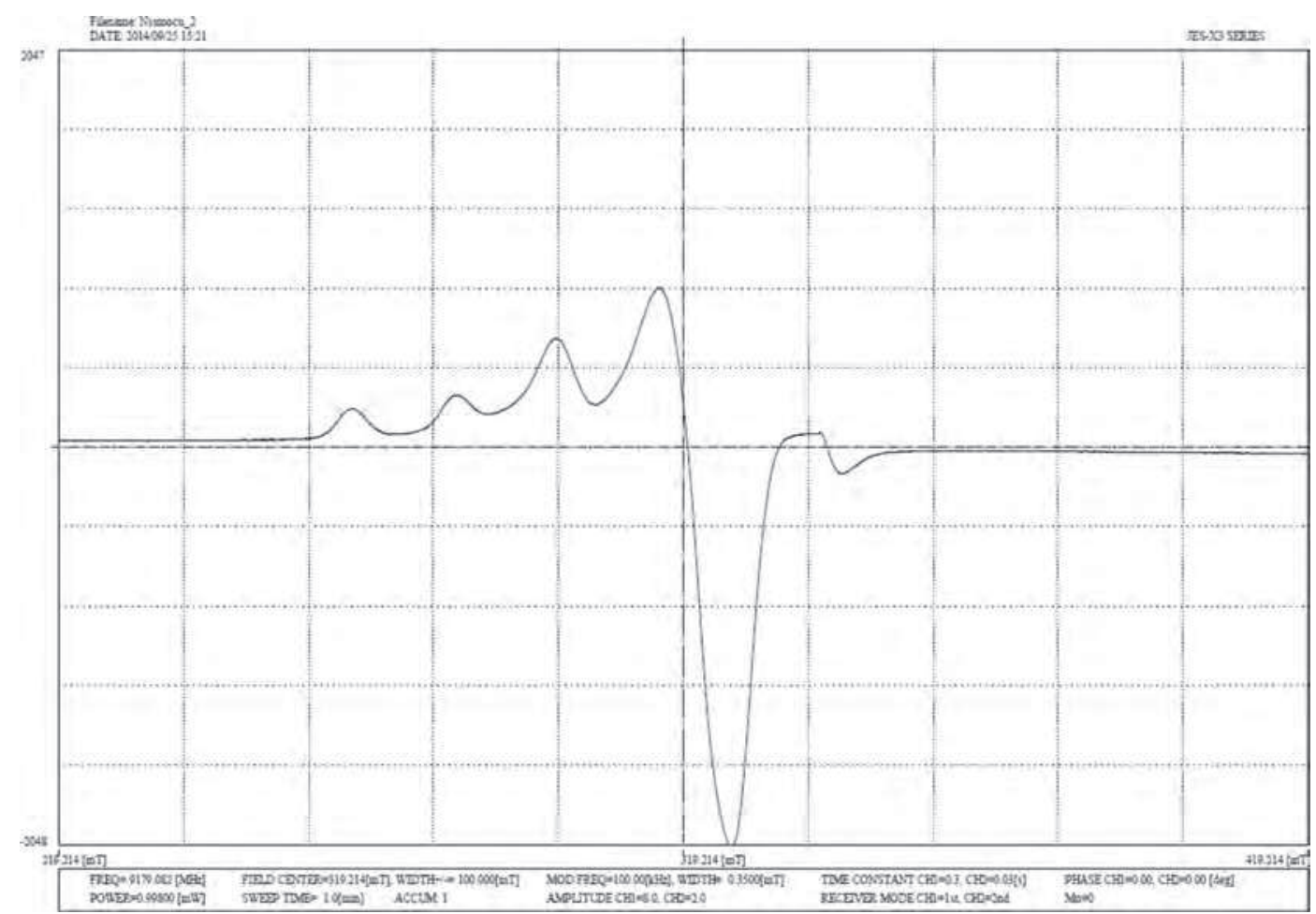

Figure 3. EPR spectrum of $\left[\mathrm{Cu}\left(\mathrm{L}^{1}\right)_{2}(\mathrm{DMF})_{2}\right]$ at liquid nitrogen temperature. 
Table 2. Selected bond distance (Á) and angles $\left(^{\circ}\right)$ for the $\mathrm{Cu}(\mathrm{II})$ Complex.

\begin{tabular}{lccc}
\hline $\mathrm{Cu}(1)-\mathrm{O}(4)$ & $1.8960(19)$ & $\mathrm{O}(4)-\mathrm{Cu}(1)-\mathrm{O}(7)$ & $95.76(8)$ \\
$\mathrm{Cu}(1)-\mathrm{N}(3)$ & $2.017(2)$ & $\mathrm{O}(4)-\mathrm{Cu}(1)-\mathrm{O}(7) \mathrm{a}$ & $84.24(8)$ \\
$\mathrm{Cu}(1)-\mathrm{O}(7)$ & $2.669(2)$ & $\mathrm{O}(7)-\mathrm{Cu}(1)-\mathrm{N}(3)$ & $92.30(8)$ \\
$\mathrm{O}(4)-\mathrm{C}(17)$ & $1.281(4)$ & $\mathrm{O}(7)-\mathrm{Cu}(1)-\mathrm{N}(3) \mathrm{a}$ & $87.70(8)$ \\
$\mathrm{N}(3)-\mathrm{C}(11)$ & $1.283(4)$ & $\mathrm{O}(4)-\mathrm{Cu}(1)-\mathrm{O}(4) \mathrm{a}$ & 180 \\
$\mathrm{O}(7)-\mathrm{C}(20)$ & $1.219(5)$ & $\mathrm{O}(7)-\mathrm{Cu}(1)-\mathrm{O}(7) \mathrm{a}$ & 180 \\
$\mathrm{O}(4)-\mathrm{Cu}(1)-\mathrm{N}(3) \mathrm{a}$ & $89.05(8)$ & $\mathrm{N}(3)-\mathrm{Cu}(1)-\mathrm{N}(3) \mathrm{a}$ & 180 \\
$\mathrm{O}(4)-\mathrm{Cu}(1)-\mathrm{N}(3)$ & $90.95(8)$ & & \\
\hline
\end{tabular}

3.2c Hydrogen bonding: There is a $\mathrm{N}-\mathrm{H} \cdots \mathrm{O}$ intermolecular hydrogen bond $[\mathrm{N} 2 \cdots \mathrm{O} 7=2.822(4)$ $\AA]$, where the amido nitrogen acts as a donor and the oxygen of the solvent molecule dimethyl formamide (O7) acts as an acceptor. This crystal structure is also stabilized by a weak C-H. . .O bonds. Atoms C3 (isoxazole) and $\mathrm{C} 6$ act as acceptors in $\mathrm{C}-\mathrm{H}$. . .O interactions with the oxygen atom (O1) of the sulfonamide group in sulfamethoxazole. This weak interaction was not observed in the packing of NSSMOCu.

\subsection{Biological activity}

3.3a Anti-microbial and anti-fungal activity: Disc diffusion technique has been used for determining the activity of Schiff base ligand and its copper complex against bacterial species and fungi. It is clear from the biological data that the ligand and the complex have significant antimicrobial activities against the pathogenic bacteria. The results compared with standard drug (Ciprofloxacin $5 \mu \mathrm{g} /$ disc for bacteria; Nystatin 100 units/disc for fungi) have indicated that compounds were active but activity was lesser than the standard drugs. Comparisons of the biological activity of the synthesized compounds with reference standard are presented in table 3, shows that copper complex exhibits better activity than free ligand against some species. The activity increases for three species and remain as such for the rest of the species. Specifically, the copper complex shows very high activity against the bacteria staphylococcus aureus, which indicates the remarkable anti-bacterial activity when compared to the rest of the species which is shown in the figure 4 . To conclude the activity of the ligand is enhanced after chelation with metal and thus the biological activity increases on complexation.

\subsection{Cytotoxic activity}

3.4a Human cell lines: Colon cancer (HCT - 116) and Breast cancer (MDA - MB - 231) cell lines were cultured in RPMI - 1640 medium with $20 \%$ FBS, $2 \mathrm{mM}$ L-glutamine, $1 \%$ penicillin streptomycin under a fully humidified atmosphere $5 \% \mathrm{CO}_{2}$ at $37^{\circ} \mathrm{C}$.

3.4b In vitro cell growth inhibition assay (MTT assay): The effect of the free ligand and its copper complex on the viability of human colon cancer cells (HCT-116) and breast cancer cells (MDA-MB-231) were assayed by the 3-(4,5-dimethylthiazol-2-yl)-2,5diphenyltetrazoliumbromide (MTT) assay. Cytotoxicity of the free ligand and copper complex were investigated on the basis of the measurements of in vitro growth in 96-well microtitre plates by cell mediated reduction of tetrazolium salt to form water insoluble formazan crystals according to the literature procedure. ${ }^{35}$ The cells

Table 3. Anti-microbial activity of the Schiff base and its copper complex.

\begin{tabular}{lcc}
\hline & \multicolumn{2}{c}{ Zone of inhibition in mm } \\
\cline { 2 - 3 } Name of the microorganisms & $\begin{array}{c}\text { Ligand } \\
\text { (NSSMO) }\end{array}$ & $\begin{array}{c}\text { Copper complex } \\
\text { (NSSMOCu) }\end{array}$ \\
\hline Staphylococcus aureus (NCIM 2079) & 16 & 25 \\
E.Coli (NCIM 2065) & 16 & 22 \\
Klebsiella aerogenes (NCIM 2098) & 20 & 20 \\
Basillus subtilis (NCIM 2063) & 18 & 18 \\
Aspergillus niger (NCIM 105) & 20 & 24 \\
Candida albicans (NCIM 3102) & 18 & 18 \\
\hline
\end{tabular}

Standard: Ciprofloxacin $5 \mu \mathrm{g} /$ disc for bacteria; Nystatin 100 units/disc. 


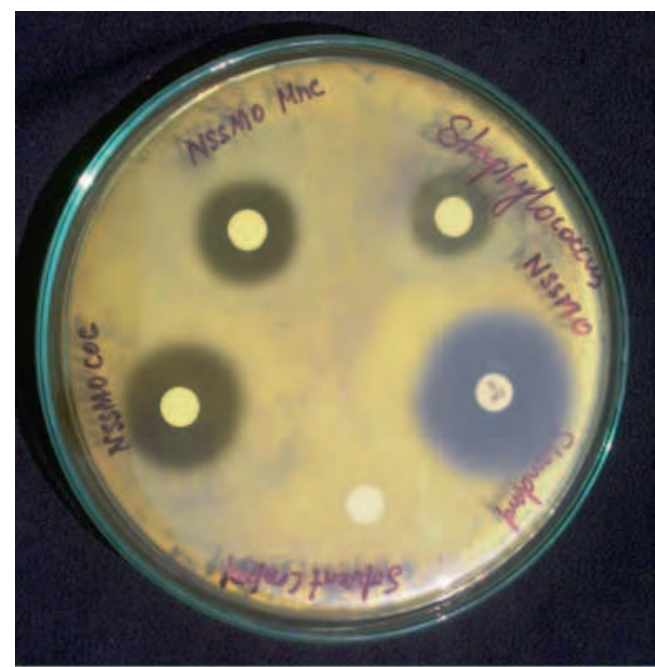

(a)

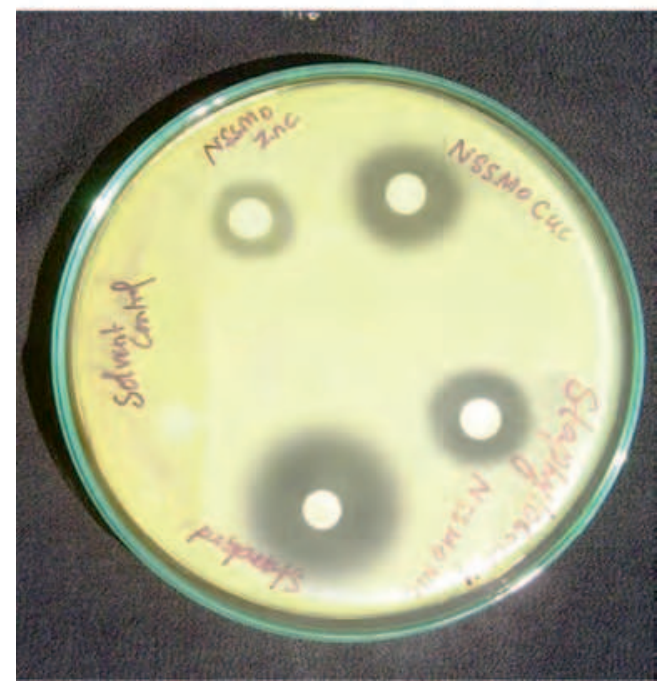

(b)

Figure 4. (a) Zone of inhibition for the ligand (NSSMO) against Staphylococcus aureus. (b) Zone of inhibition for the complex (NSSMOCuC) against Staphylococcus aureus.

were seeded in 96-well plates at a concentration of $1 \times 10^{4}$ cells/well in $100 \mu \mathrm{L}$ of complete media and incubated for 24,48 and $72 \mathrm{~h}$ at $37^{\circ} \mathrm{C}$ in $5 \% \mathrm{CO}_{2}$ atmosphere to allow for cell adhesion. The compounds were tested for cytotoxicity against two different tumour cell lines mentioned above. The Schiff base ligand is found to be non-toxic but the complex showed excellent cytotoxicity toward MDA-MB-231 $\left(\mathrm{IC}_{50}=6.48\right)$. The same complex exhibited considerably high $\mathrm{IC}_{50}$ value $\left(\mathrm{IC}_{50}=53.73\right)$ against HCT 116 . So the complex is specific in action towards breast cancer cell line and less toxic towards colon cancer cell line. The anti-cancer activities $\left(\mathrm{IC}_{50}\right)$ of cisplatin, carboplatin and NSS$\mathrm{MOCu}$ against each cancer cell lines are also shown in table 4 . The $\mathrm{IC}_{50}$ values of each drug were calculated from the dose-survival curves obtained from the MTT assay. NSSMOCu was observed to be more effective than cisplatin and carboplatin in breast cancer cell lines. These results suggest that NSSMOCu is more effective than either cisplatin or carboplatin in human breast cancer, in vitro. From these results it is evident that ligand is non-toxic in nature but its copper complex shows excellent cytotoxicity towards breast cancer. The presence of metal ion $\mathrm{Cu}^{2+}$ enhances the cytotoxic activity significantly. The better cytotoxic activity of copper complex against breast cancer cell line strongly supports the significance of metallodrug design in medicinal inorganic chemistry.

\section{Conclusions}

The synthesis of copper complex of the Schiff base ligand $\mathrm{HL}^{1}$, which is a derivative of sulfamethoxazole and 5-nitro salicylaldehyde, is described. The structure of the complex corresponds to a six-coordinate monomeric $\mathrm{Cu}^{\mathrm{II}}$ complex, the binding set includes two phenolatooxygens, two imine nitrogens of the ligand and two carbonyl oxygen atoms of the solvent DMF, and the geometry being distorted octahedron. The analysis of the EPR spectra and magnetic susceptibility data revealed a clear correlation with the structure of the analyzed complex and the longer coordination bond in axial position is described by the Jahn-Teller effect. The biological activity of the ligand is enhanced after complexation with metal.

Table 4. In Vitro anti-cancer activity of the Schiff base and its copper complex.

\begin{tabular}{lcc}
\hline \multirow{2}{*}{ Compound } & \multicolumn{2}{c}{$\mathrm{IC}_{50}(\mu \mathrm{m})$} \\
\cline { 2 - 3 } & $\mathrm{HCT}-116$ & $\mathrm{MDA}-\mathrm{MB}-231$ \\
\hline $\mathrm{HL}^{1}$ & $>10$ & $>10$ \\
{$\left[\mathrm{Cu}\left(\mathrm{L}^{1}\right)_{2}(\mathrm{DMF})_{2}\right]$} & 53.73 & 6.48 \\
Cisplatin $^{36}$ & 13.10 & 13.98 \\
Carboplatin $^{36}$ & 69.44 & 68.26 \\
\hline
\end{tabular}

The experimental results are presented as micro-mole concentration of $50 \%$ cell growth inhibition $\left(\mathrm{IC}_{50}\right)$ of each drug. 


\section{Supplementary Information}

CCDC 985349 contains the supplementary crystallographic data for NSSMOCu. These data can be obtained free of charge via http://www.ccdc.cam.ac. uk/conts/retrieving.html, or from the Cambridge Crystallographic Data Centre, 12 Union Road, Cambridge CB2 1EZ, UK; fax: (+44)1223-336-033; or e-mail: deposit@ccdc.cam.ac.uk. Supplementary information on elemental analysis data, EPR and NMR spectra are available at www.ias.ac.in/chemsci.

\section{Acknowledgements}

The authors are thankful to the Director, SAIF, IIT, Chennai, STIC, Cochin, Kerala, CECRI, Karaikudi and SRM University, Kattankulathur for providing analytical support. The authors also thank the Secretary, Principal and Faculty members of Chemistry, Seethalakshmi Ramaswami College, Trichy, Tamil Nadu for providing laboratory facilities and support.

\section{References}

1. Rathelot P, Vanelle P, Gasquet M, Delmas F, Crozet M P, Timon David P et al. 1995 Eur. J. Med. Chem. 30503

2. Shi L Ge H M, Tan S H, Li H Q, Song Y C, Zhu H L et al. 2007 Eur. J. Med. Chem. 42558

3. Karthikeyan M S, Prasad D J, Poojary B, Bhat K S, Holla B S and Kumari N S 2006 Bioorg. Med. Chem. 14 7482

4. Wang P H, Keck J G, Lien E J and Lai M M C $1990 \mathrm{~J}$. Med. Chem. 33608

5. Hearn M J and Cynamon M H 2004 J. Antimicrob. Chemother. $\mathbf{5 3} 185$

6. More P G, Bhalvankar R B and Pattar S C 2001 J. Indian Chem. Soc. 78474

7. Chandra S and Sangeetika R A 2001 J. Saudi Chem. Soc. 5175

8. Bult A 1982 Met. Ions Biol. Syst. 16261

9. Goodgame D M L, Hill S P W and Williams D J 1992 Polyhedron 111507

10. Vogel A I 1989 In Textbook of Practical Organic Chemistry $5^{\text {th }}$ Edition (London: Longman)

11. SMART, 1997 Data collection program for CCD Area - Detector system; SAINT, Data Reduction and Frame Integration Program for CCD Area - Detector System. Bruker Analytical X-ray Systems, Madison, WI, USA
12. Sheldrick G Program SADABS: 1996 Area-Detector Absorption Correction, University of Gottingen, Gottingen, Germany

13. Sheldrick G M SHELXS-97, SHELXL-97: 1997. Programs for crystal structure analysis, University of Gottingen, Gottingen, Germany

14. (a) Farrugia L J 1997 J. Appl.Crystallogr. 30 565; (b) Farrugia L J Crystal Clear ${ }^{\mathrm{TM}}$ software, Rigaku Inc., Texas, USA 2005 G.M. Sheldrick, SHELXS-97, SHELXL-97: 2001 Programs for crystal structure analysis, University of Gottingen, Gottingen, Germany; (c) K Brandenburg. DIAMOND, Crystal Impact GbR, Bonn, Germany

15. Hingorani S Agarwala BV1993 Transition Met. Chem. 18576

16. Maurya R C, Mishra D D and Rao N S 1992 Polyhedron 112849

17. Geary W J 1971 Coord. Chem. Rev. 781

18. Lever A B P, Lewis J and Nyholm R S 1963 J. Chem. Soc. 592552

19. Bellamy L J 1971 In The Infrared Spectra of Complex Molecules (New York: John Wiley)

20. Rama I and Usha V 2013 Asian J. Chem. 256 p. 3225

21. Gomathi V and Selvameena R 2013 Asian J. Chem. 25 4 p. 2083

22. Valarmathy G and Subbalakshmi R Asian J. Chem. 254 p. 2077

23. Soliman A A 1997 Spectrochim. Acta Part A 53509

24. Andersen K B and Spanget-Larsen 1997 Spectrochim. Acta Part A $\mathbf{5 3} 2615$

25. Mukherjee T, Pessoa J C, Kumar A and Sarkar A R 2013 Dalton Trans. 422594

26. Raman N, Johanson Raja S, Joseph J, Sakthivel A and Dhaveethu Raja J 2008 J. Chil. Chem. Soc. 53(3) 1599

27. Singh K, Naganagowda G A and Aganvala B V 1996 Ind. J. Chem. Sect. A 35 A67

28. Zahid H Chohan, Claudiu T Supuran 2008 J. Enyme. Inhib. Med. Chem. 23(2) 240

29. Pasto D J 1969 In Organic structure determination (London: Prentice Hall)

30. Kivelsen D and Neiman R 1961 J. Chem. Phys. 35149

31. Syamal A and Singh M M 1992 Ind. J. Chem. Sect. A 31A 110

32. Hathway B J and Billing D E 1961 Coord. Chem. Rev. 5 143

33. Ismail M A 2005 J. Coord. Chem. 58141

34. James E Huheey, Ellen A Keiter and Richard L Keiter 1997 In Inorganic chemistry: Principles of structure and reactivity $4^{\text {th }}$ Edition (Pearson) p. 452

35. Navarra M, Celano M, Maiuolo J, Schenone S, Botta M, Angelucci A, Bramanti P and Russo D 2010 BMC Cancer 10602

36. Kwon Y-E, Park J-Y and Kim W-K 2007 Anticancer Res. 27321 